Article

\title{
The Narrative's Creative and Ethical Mediation: A Refigured Self, a Refigured World
}

\section{Kelly Louise Rexzy P. Agra}

\begin{abstract}
In the age-old divide between philosophy and the arts, one can situate most compellingly Paul Ricoeur's take on the narrative which best highlights the creative or even cathartic dimension of art, particularly literature, in the configuration of the self. He argues that a work of art is not a simple imitation, rather, it is always and already a creative imitation---a new take, a different rendering, a refiguration of reality that discloses multi-layered truths, referring to a world and projecting other possible worlds. Ricoeur follows Aristotle in this view on mimesis but he goes on to develop it into a triad of mimetic activity wherein one could draw an aesthetic and ethical import, as it treats a work of art as one that speaks of realities that are not immediately given nor could simply be encapsulated and reduced to logical and scientific descriptions. Ricoeur here is not simply making an apology of the arts, instead he is presenting the mediating role of the narrative in understanding human action and its meaning and ultimately, oneself, within the horizon of temporal existence. This paper is a reflection of Ricoeur's portrayal of the narrative which echoes the reality that it is in the stories told and heard, written and read, lived and narrated wherein anyone can see that after all, the mystery of life and the joyful struggle for living is shared by everyone else. Through narration, imaginative and ethical variations, different worlds and ways of living are opened up. In recounting one's life, one is able to form and share an understanding of oneself and one's world, that is not substantial but rather dynamic, ever available to transform and be transformed.
\end{abstract}

Keywords: Ricoeur, narrativity, literature, ethics

(c) 2014 Kelly Louise Rexzy P. Agra

http://www.kritike.org/journal/issue 15/agra december2014.pdf

ISSN 1908-7330

(cc) BY-NC 
.. . we have no idea of what a culture would be where no one any longer knew what it meant to narrate things.

Paul Ricoeur, Time and Narrative

"W hat fault do you find in them?" Adeimantus asked Socrates referring to the poets, in their discussion of the literary education suitable for the republic. To which Socrates replied: "The worst fault possible, especially if the fiction is an ugly one ... Misrepresenting the nature of gods and heroes, like a portrait painter whose portraits bear no resemblance to their originals ... a fault which certainly deserves censure." 1 This conversation found in Plato's The Republic, portrays one of the controversies western philosophy has been involved in in asserting its believed privileged position towards the pursuit of the good life. ${ }^{2}$ Such position that regards rhetoric, poetry, and art in general as inferior, for what they present are twice removed from reality, as they are only imitations of imitations, and worse, they corrupt philosophy's most prized 'Reason.' 3

In this divide between philosophy and the arts, one can situate most compellingly Paul Ricoeur's take on the narrative, which best highlights the creative or even cathartic dimension of art, particularly literature, in the configuration of one's identity. One finds in Ricoeur an appreciation of a work of art not as a simple imitation, rather, as an always and already creative mimesis, a refiguration of reality that discloses multi-layered truths, referring to a world, and projecting possible worlds one could imagine oneself inhabiting. Ricoeur follows Aristotle in this view on mimesis but he goes on to develop it into a triad of mimetic activity: prefiguration, configuration, refiguration-which could be found in his three volume work Time and

${ }^{1}$ Plato, The Republic, trans. by Desmond Lee (London: Penguin Books, 2007), 377d-e, 69. Note that the last phrase was Adeimantus' reply to Socrates, "a fault which certainly deserves censure."

2 The 'Good' in Plato is the supreme "end of all endeavour, and the object on which every heart is set" for it is "the source not only of the intelligibility of the objects of knowledge, but also of their being and reality"-- the ultimate goal of the soul. The use of the phrase 'good life' here is to refer to a general disposition for living a good life. Following Ricoeur, it is "the nebulus of ideals and dreams of achievements with regard to which a life is held to be more or less fulfilled or unfulfilled. [ ... ] it is 'that in view of which' all [ ... ] actions are directed, actions which were nevertheless said to have end in themselves." Paul Ricoeur, Oneself as Another, trans. by Kathleen Blamey (Chicago and London: The University of Chicago Press, 1994), 179. [Hereafter cited as $O A A$.]

${ }^{3}$ Michael Weston writes in the introduction of his book Philosophy, Literature and the Human Good, "It began of course, with Plato, who announced that there had long been a quarrel between philosophy and poetry." In this book, Weston explores philosophical and literary figures that directly or indirectly tackle this long battle between literature or art and philosophy such as Kant, Schlegel, Nietzsche, Bataille, Blanchot, Derrida, Murdoch, Nussbaum, Rorty, Cavell, Kierkegaard, Phillips. See Michael Weston's Philosophy, Literature and the Human Good (London and New York: Routledge, 2001).

(c) 2014 Kelly Louise Rexzy P. Agra

http://www.kritike.org/journal/issue 15/agra december2014.pdf

ISSN 1908-7330 
Narrative. He treats a work of art as one that speaks of realities that are not immediately given nor could simply be encapsulated and reduced to logical and scientific descriptions. In The Rule of Metaphor Ricoeur speaks of this creative character of poetry and writes, "Poetry does not seek to prove anything at all: its project is mimetic; its aim ... is to compose an essential representation of human actions." 4

Ricoeur here is not simply making an apology of the arts. Instead, he is presenting the mediating role of art in understanding human action and its meaning, and ultimately, oneself, within the horizon of temporal existence. The intertwining of time and narrative is proposed by Ricoeur as an alternative in remedying the fatal deficiency in any purely phenomenological approach. It is a response to what he saw was the danger of Heidegger's direct ontologization of human existence as he asserts that there is more than one way to talk about being. Time-as that within which we exist as finite human beings, acting and suffering at the same time, in a world we inhabit with others - "becomes human time to the extent that it is organized after the manner of a narrative; the narrative, in turn, attains its full meaning when it becomes a condition of temporal existence." 5

\section{The Creative Power of Literature}

At least once, in someone's life, one experiences an utter powerlessness to articulate what one feels that one is ready to trust that no amount of literature would ever suffice to represent the depth of an experience that overwhelms one's being. Perhaps these are the instances that lead one to suppose that maybe there is a God, whose power stretches far beyond anything that could be conceived. Such instances convince one of the mystical, the tormenting, or the dreadful, when there seem to be nothing but intoxication, torture, or horror! These are the experiences wherein the cogito in all its assertiveness can never deny that event when it is drawn from thinking. The ' $\mathrm{I}$ ' then crumbles into a kind of infinity where every purpose,

${ }^{4}$ Paul Ricoeur, The Rule of Metaphor: The Creation of Meaning in Language (London and New York: Routledge, 2003), 13.

A scholar on Ricoeur, David Pellauer comments, "Aristotle considered rhetoric and poetic discourse - even their use of metaphor and other figurative forms - to overlap logic because of the appeal to some form of argumentation they both include." " ... rhetorical argument introduces the idea of creativity ... " He adds that the semantic innovation in metaphor, its transgressive and transformative aspect "is what makes it capable of creating new meaning by disturbing the existing logical order at the same time that it begets it in a new form ... it makes us see things differently, not by imitating them in the sense of producing a copy but by redescribing them." David Pellauer, Ricoeur: Guide for the Perplexed (London and New York: Continuum, 2007), 67.

5 Paul Ricoeur, Time and Narrative (Chicago: Chicago University Press, 1984), 1:3. [Hereafter cited as TEN, followed by the volume and page number].

(c) 2014 Kelly Louise Rexzy P. Agra

http://www.kritike.org/journal/issue 15/agra december2014.pdf

ISSN 1908-7330

(cc) $\mathrm{BY}-\mathrm{NC}$ 
every thought and every doubt simply fades, for nothing else exists except that genuine moment that at once made it feel most alive. To recount such times would even seem foolish just when one already believed that they could not be spoken of if not in approximation. Yet, one cannot help but consider that these events deserve to be recounted, 'because in the last analysis human lives need and merit being narrated.' ${ }^{6}$

It is therefore in such enigma of experience wherein Paul Ricoeur finds the language of imagination available in literature asserting its power. Literature for him creatively gives a closer approximation of reality and experience than that of science's, logic's, or even phenomenology's direct descriptions. Likewise, it highlights a tempering of the tension between being wary of not thinking that language could contain reality, but believing so that language can touch this reality. In the field of figurative discourse, Ricoeur takes the metaphor's transgressive aspect that disturbs commonplace understanding, and the network of reference and expectation, as that which makes possible the redescription of things.

In the opening lines of Time and Narrative, Ricoeur stresses that The Rule of Metaphor and Time and Narrative must be taken together as a pair. For it is in both where he brings out the similarities between the metaphor and the narrative. The first of these is their capacity to display the creativity of language. ${ }^{7}$ He writes,

The work of art-having an effect comparable to that of metaphor in integrating levels of sense that are overlaid, preserved and contained together-is the occasion for discovering aspects of language that are ordinarily concealed by its usual practice, its instrumentalized function of communication. The work of art bares properties of language which otherwise would remain invisible and unexplored. ${ }^{8}$

Ricoeur calls this 'semantic innovation.' He says, "in both cases, the new thing - the as yet unsaid-springs up in language." ${ }^{\prime \prime}$ If the metaphor is able to give birth to new meanings by coupling terms which do not belong to

\footnotetext{
${ }^{6} \mathrm{TEN}, 1: 75$.

${ }^{7}$ See Leovino Ma. Garcia's “Paul Ricoeur's Happy Memory: Remembering, Forgetting, Forgiving," in Thought the Harder, Heart the Keener: A Festschrift for Soledad S. Reyes, ed. Eduardo Jose Calasanz, Jonathan Chua, Rofel Brion (Loyola Schools, Ateneo de Manila University: Office of Research and Publications, 2008), 3.

8 Paul Ricoeur, "Aesthetic Experience," in Critique and Conviction: Conversations with Francois Azouvi and Marc de Launay, trans. Kathleen Blamey (Cambridge, UK: Polity Press, 1998), 172.

${ }^{9}$ TEN, 1:ix.
} 
the same semantic field, the narrative-by invention of the plot-synthesizes heterogeneous elements in order to project a complete story. ${ }^{10}$ This synthetic operation both within the metaphor and the narrative makes possible the infinite combination of elements and of thought experiments that could only happen within the realm of imagination.

The second similarity that he draws from the two is found on the level of their reference or truth-claim. ${ }^{11}$ This presupposes that literature primarily refers to a network of human activity and experience. Inasmuch as it is a human creation, it is necessarily grounded within a situation from which it can only arise. This is its first reference: it refers to a particular world where it can only be thought of. However, this reference to a world is accompanied by an opening of another world: 'the kingdom of the as if.'12 This is its second reference: the 'world of the text' or the story itself. Through human action's configuration in a plot, the narrative enables the projection of heterogeneous values, and referential frameworks involved in temporal existence. The narrative in exposing multiple possibilities of living under given social and historical circumstances is thus able to present truth as a matter of existential appropriation and not of intellectual argument. ${ }^{13}$

In such presentation, the power of literature comes in three waves. First, it provides a space for an articulation of experiences that cannot be expressed through a direct or definitive description. Second, it brings to language the possibility for a new take on reality; it unsettles, challenges, and remodels human expectations. Third, it is not the case that literature is out of this world; it actually refers to a world and is a product of it. And by its creativity, it is also able to project other possible worlds that contribute to the widening of our cognitive fields.

\section{The Ethical Dimension}

If living is just living alone, perhaps the tensions brought to the fore by ethics would not at all be relevant. If self-autonomy is all that matters, tragedy, or the novel may not have been invented. If the world does not disclose the reality that we are beings-with-others, we may not even have an idea of what a family is. One characteristic of the narrative is that it consists of characters who act and suffer in the field of social interaction and in everyday life. The narrative, with its proposition of a world likewise proposes conditions where there is a need for an exercise of moral judgment, circumstances where the spectator is drawn to feel with the actor's struggle

\footnotetext{
${ }^{10}$ Garcia, "Paul Ricoeur's Happy Memory," 4.

${ }^{11}$ Ibid.

12 TEN, 1:64.

${ }_{13}$ Weston, Philosophy, Literature and the Human Good, xix.
}

(C) 2014 Kelly Louise Rexzy P. Agra

http://www.kritike.org/journal/issue 15/agra december2014.pdf

ISSN 1908-7330

(cc) BY-NC 
to press for a decision, and situations that illustrate expected and unexpected outcomes. This is because actors are not sole actors in the practical field, they are with and against other beings with whom they share the struggle for life and the finite attempts to overcome their weaknesses. In the same way that the stories we read, watch, and hear present new worlds from which we could derive hope, inspiration, and understanding, stories offer us hints on how to interact and relate with other people.

Ricoeur proceeds to assert that action can never be ethically neutral. In light of this, he reminds us of one of the oldest functions of art: that it constitutes an ethical laboratory where the artist pursues through the mode of fiction experimentation with values. As he writes, "Telling a story is at the same time deploying an imaginary space for thought experiments in which moral judgment operates in a hypothetical mode."14 From this we draw Ricoeur's attempt to wed ethics with aesthetics as he sees it to be initially manifest in a work of art, and that being the case, it is as evident in the narrative. He stresses,

... the practical understanding authors share with their audiences necessarily involves an evaluation of the characters and their actions in terms of good and bad. There is no action that does not give rise to approbation or reprobation, to however small a degree, as a function of a hierarchy of values for which goodness and wickedness are the poles. ${ }^{15}$

The narrative is a projection of ethical possibilities. The novel for one, more than being unrelated to reality or a mere story of a happy ending, extends into the social sphere. It re-channels our attention to lives and events that are not always monumental but nonetheless exert a forceful emulation of the everyday lives of ordinary people in its own creative way. Hence, when we read these stories, it is not too difficult for us to relate and feel with the characters precisely because our own lives share a particular resemblance with the lives of the characters. The themes of love, jealousy, desire, weakness, forgiveness, desperation, and all else, which at times almost leave us dumbstruck no matter how trivial they may appear in contrast with the problems of the world, are given attention and significance. For is it not that at the end of the day, our immediate concerns inflict us more gravely?

Meanwhile, what the narrative also enables is the self's recognition of itself. The narrative becomes a tool for a 'hermeneutics of the self.' From the very start, Ricoeur stresses that there is no direct way of understanding

$14 O A A, 170$.

${ }^{15} T \mathcal{O E N}, 1: 59$.

(c) 2014 Kelly Louise Rexzy P. Agra

http://www.kritike.org/journal/issue 15/agra december2014.pdf

ISSN 1908-7330 


\section{CREATIVE AND ETHICAL MEDIATION}

ourselves. The self can only be interpreted through the long detour of signs and symbols of human action, and these are brought to light in the realm of discourse and interpretation through narration. The self of self-knowledge is the fruit of an examined life, purged and clarified by the cathartic effects of narratives handed down by one's culture. ${ }^{16}$ One recognizes oneself in the stories one tells about oneself, borrowing from fiction and history, ways to recount. ${ }^{17}$ Recalling Marcel Proust's lines from Time Regained, Ricoeur quotes him:

But to return to myself, I thought more modestly of my book, and one could not exactly say that I thought of those who would read it, of my readers. Because they would not according to me be my readers, but the real readers of themselves ... . It was my book, and thanks to it I enabled them to read what lay within themselves. ${ }^{18}$

Through an account of the ethical dimension of the narrative Ricoeur reminds us of three things. First, the self is a result, a product of culture and history. In place of an ego enamored of itself is a self, instructed by narratives. ${ }^{19}$ Insofar as every narrative is a configuration of multiple events and characters, we, as narrative-selves, are assemblages of all the forces that have thus affected, informed, and moved us. Second, inasmuch as every narrative opens itself to unlimited interpretations and re-interpretations, it is also in our capacity to continually figure and refigure our identities. This is where Ricoeur develops what he calls 'narrative identity.' We are a constant project, and while we still feel the warmth of our breaths, we can change. Third, as we all are but travelers in search of ourselves, Ricoeur invites us to let our own stories be heard, for maybe somewhere in a bitter cold night, it could touch and inspire a soul, likewise determining himself, ready to transform and be transformed. At the bottom of it all, the narrative crystallizes a purged self who understands life as really a life with others.

\section{Conclusion: Refiguration through the Narrative}

The narrative, presented as performing a creative-ethical mediation, now unfolds its significance in relation to man's understanding of time, life, human action, the world, and himself. As the narrative asserts its power in

\footnotetext{
16 Ricoeur stresses: "self-constancy refers to a self instructed by the works of culture it has applied to itself." TEN, 3:247.

17 Paul Ricoeur, "Narrative Identity," in On Paul Ricoeur: Narrative and Interpretation, ed. by David Wood (New York: Routledge, 1991), 188. [Hereafter cited as NI].

${ }^{18}$ Cf. Marcel Proust, “Time Regained," trans. by David Wood in NI, 198.

19 Paul Ricoeur, "Life in Quest of Narrative," in On Paul Ricoeur: Narrative and Interpretation, ed. by David Wood (New York: Routledge, 1991), 33. [Hereafter cited as LQN.]

(c) 2014 Kelly Louise Rexzy P. Agra http://www.kritike.org/journal/issue 15/agra december2014.pdf ISSN 1908-7330 
disclosing human realities that could only be made available through the discourse it transmits, it brings to the fore tensions which in Ricoeur turn out to be complementary. The first tension is the very title of his book where he developed his theory of the narrative: Time and Narrative.

'In narrative discourse, we may find a refigured time that in the best of cases help us make better sense of the ordinary everyday time of our lives as well as of its limit situations.' ${ }^{20}$ Such enhanced understanding is so that we may allow new forms of narrative configuration to rise-an understanding of reality as not permanent nor absolute, but temporal - joyfully affirming the transitory nature of things and even our finite lives. The narrative, as it constructs and unifies diverse aspects of temporal existence achieves its full meaning and is able to make time, human time. We learn from Heidegger that to be temporal always means to be 'in time.' Temporality is the meaning of our being. Our lives are the entire stretch of how we had been and will be between our births and deaths. The narrative, therefore, receives the role of synthesizing all the factors, events, encounters, and social roles involved in one's existence that contribute to the determination of one's series of decisions. Such decisions work against the backdrop of facticity but are truly 'owned.' Our situatedness determines our possibilities, but it is we who decide which possibility to actualize. It is our choices which lead to sets of consequences that make us who we are, transforming our lives into living narratives of our identities. All these are crafted into a story of an individual who at once graced the world and shared with the entire humanity the living projection of how it is to be human-a configuration that inasmuch as it is not closed in upon itself, is ever open for the limitless ways of being recounted, by others and within different contexts, a story that can be heard and read, and when understood, contributes to the refiguring of our understanding of human action and its possibilities. ${ }^{21}$ Following the poem's invitation, narrating, telling, and reciting turns out to be a remaking of action, which in its own way will re-signify the world in its temporal dimension. ${ }^{22}$

If Ricoeur is able to bridge time and narrative, he is also able to unify Fiction and Life. Like all narratives, fiction too presents a world of the text in which the story is understood to unfold. ${ }^{23}$ Fiction, being a laboratory for ethical judgment, in its openness to infinite thought experiments about ways and means of existing in inexhaustible situations, allows the world to be seen differently, but also, in perspectives that could be true of the world as it

\footnotetext{
20 Pellauer, Ricoeur: Guide for the Perplexed, 73.

${ }^{21}$ Ibid., 72.

22 This is an allusion of what Ricoeur said, that "the narrative re-signifies the world in its temporal dimension, to the extent that narrating, telling, reciting is to remake action following

${ }^{23}$ Pellauer, Ricoeur: Guide for the Perplexed, 77.
} the poem's invitation." TEN, 1:81. 


\section{CREATIVE AND ETHICAL MEDIATION}

actually is or might be. Fiction becomes a way of articulating new experiences of time, of fictive experiences that help us better understand our own world. ${ }^{24}$ For Ricoeur, the way we interpret our lives will always be quasi-past and quasi-fictive. A life, he says, is no more than a biological phenomenon as long as it has not been interpreted. ${ }^{25}$ It is not the case that we live life and merely read fiction precisely because 'reading is already a way of living in the fictive universe $^{26}$ of a story. Stories are recounted, but in addition to that, they are lived; they come to life, in the field of imagination. The reason why we cry, laugh, get irritated, or feel in love after watching a film or hearing a narrative is because as their plots unfold toward their endings, we can follow and relate to their flow even only by imagining them. And as we listen, watch, or read, we let ourselves be immersed and engaged with different worlds. We lose ourselves for our consciousnesses are directed to the stories' horizons. And while Ricoeur refers to the paradox of an active-recipient in the being of the reader, he accentuates more than anything the broadening of the reader's horizon. This way, the narrative that creatively mediates fiction and life can be seen as an arena of imaginative and ethical variations that can be appropriated by selves who are both readers and authors of their lives.

Finally, what narration succeeds in doing is the ever-dynamic corefiguration of the Self and of the World. Literature as serving a mediating function attempts to discover new features of referentiality which are not descriptive, features of communicability which are not utilitarian, and features of reflexivity which are not narcissistic. ${ }^{27}$ It is by being in this world that we receive stories, and since we are not merely passive recipients of historical fictions or fictional histories, nor inactive observers of what happens in the society, it is also by being in this world that we actually are able to craft and tell a story. Because we are in the world and are affected by situations, and we try to orient ourselves in them, we also have something to say; we also have an experience to bring to language and to share. ${ }^{28}$ As such, what Gadamer calls as the 'fusion of horizons' is not just a fusion of the worlds of two or a few individuals; the fusion at large is the fusion of all possible horizons within the one big horizon, that is the world. Our selves are constantly refigured because we primordially exist in a world where we get to encounter and be encountered by other selves that are also in constant refiguration. And, insofar as we are individuals shaped by our own historical situatedness, these other selves to whom we stand in opposite but in mutual regard, are to us, truly 'others.' For only what is different from us can change

\footnotetext{
${ }^{24}$ Ibid., 79.

${ }^{25} L Q N, 27-28$.

${ }^{26} L Q N, 27$.

${ }^{27} L Q N, 27$.

${ }^{28} T \mathcal{E} N, 1: 78$.
}

(c) 2014 Kelly Louise Rexzy P. Agra

http://www.kritike.org/journal/issue 15/agra december2014.pdf

ISSN 1908-7330

(cc) $\mathrm{BY}-\mathrm{NC}$ 
and enlarge us. This acknowledgment of others and their worlds as really different from ours is what makes possible our co-belonging and codetermination in a world that mediates our worlds - to use Nishida Kitaro's term: a 'world of worlds.' ${ }^{29}$ Yet, this world within which we live is also refigured by us. The world is not the world without us - beings who are born and who pass away, but not without bringing something new - for it is our individual and intersecting worlds that constitute this world. We determine the world as it determines us. Every movement, every change, every creation affects and refigures everything else precisely because everything is interconnected. To recall a line from The Storyteller by Walter Benjamin, "The art of storytelling is the art of exchanging experiences." 30 Life inasmuch as it is temporal could only be lived once, so live in such a way that it could touch and inspire other souls; live without forgetting that in every encounter, our selves and our worlds are constantly refigured.

Department of History and Philosophy, University of the Philippines-Baguio, Philippines

\section{References}

Benjamin, Walter, The Storyteller: Reflections on the Works of Nilokai Leskov, $<$ http://slought.org/files/downloads/events/SF_1331-Benjamin.pdf $>$.

Davis, Bret W., "Toward a World of Worlds," in Frontiers of Japanese Philosophy, Vol. 1 (Nagoya, Japan: Nanzan Institute for Religion and Culture, 2006), 205-245.

Garcia, Leovino Ma., "Paul Ricoeur's Happy Memory: Remembering, Forgetting, Forgiving," in Thought the Harder, Heart the Keener: A Festschrift for Soledad S. Reyes, ed. by Eduardo Jose Calasanz, Jonathan Chua, RofelBrion (Loyola Schools, Ateneo de Manila University: Office of Research and Publications, 2008).

Pellauer, David, Ricoeur: Guide for the Perplexed (London and New York: Continuum, 2007).

Plato, The Republic, trans. by Desmond Lee (London: Penguin Books, 2007).

Ricoeur, Paul, "Aesthetic Experience," in Critique and Conviction: Conversations with Francois Azouvi and Marc de Launay, trans. by Kathleen Blamey (Cambridge, UK: Polity Press, 1998).

29"Sekai-tekisekai" or "world of worlds" is an idea borrowed from Kitaro Nishida which refers to the world as a place of unity-in-diversity, for the interaction of a plurality of singular worlds. See Bret W. Davis' "Toward a World of Worlds," in Frontiers of Japanese Philosophy, Vol. 1 (Nagoya, Japan: Nanzan Institute for Religion and Culture, 2006), 205-245.

30 Walter Benjamin, The Storyteller: Reflections on the Works of Nilokai Leskov, 1, $<$ http://slought.org/files/downloads/events/SF_1331-Benjamin.pdf $>$.

(c) 2014 Kelly Louise Rexzy P. Agra

http://www.kritike.org/journal/issue 15/agra december2014.pdf

ISSN 1908-7330 


\section{CREATIVE AND ETHICAL MEDIATION}

On Paul Ricoeur: Narrative and Interpretation, ed. by David Wood (New York: Routledge, 1991).

Oneself as Another, trans. by Kathleen Blamey (Chicago and London: The University of Chicago Press, 1994). The Rule of Metaphor: The Creation of Meaning in Language (London and New York: Routledge, 2003).

Time and Narrative (Chicago: Chicago University Press, 1984).

Weston, Michael, Philosophy, Literature and the Human Good (London and New York: Routledge, 2001). 